\title{
Factors Controlling Magnetism of Reddish Brown Soil Profiles from Calcarenites in Southern Spain: Dust Input or In-situ Pedogenesis?
}

\author{
Qingsong Liu ${ }^{1,2 *}$, Chunxia Zhang ${ }^{3}$, José Torrent ${ }^{4}$, Vidal Barrón ${ }^{4}$, Pengxiang $\mathrm{Hu}^{5}$, \\ Zhaoxia Jiang ${ }^{1,2}$ and Zongqi Duan ${ }^{1,2}$ \\ 'State Key Laboratory of Lithospheric Evolution, Institute of Geology and Geophysics, Chinese Academy of Sciences, \\ Beijing, China, ${ }^{2}$ Laboratory for Marine Geology, Qingdao National Oceanography Laboratory for Science and Technology, \\ Qingdao, China, ${ }^{3}$ Key Laboratory of Cenozoic Geology and Environment, Institute of Geology and Geophysics, Chinese \\ Academy of Sciences, Beijing, China, ${ }^{4}$ Departamento de Agronomía, Universidad de Córdoba, Córdoba, Spain, ${ }^{5}$ Research \\ School of Earth Sciences, Australian National University, Canberra, Australia
}

Under aerobic conditions, the A and B horizons of soils are magnetically enhanced due to neoformation of ferrimagnets through pedogenesis. This study systematically investigated soils developed on calcarenites of Neogene age in southern Spain to determine the dominant factors controlling the soil magnetism. Geochemical and clay mineral analyses indicate that aeolian dust significantly contribute to the A and B horizon material of the Spanish soil. Nevertheless, the magnetic enhancement of soils can be simply attributed to the pedogenically produced ferrimagnets in-situ. Therefore, the magnetism of Spanish soils is still linked to paleoclimatic variations regardless of the complexities of aeolian inputs from the Northwestern Africa.

Keywords: Spanish soil, Sahara dust, pedogenesis, magnetism, ferrimagnet

\section{INTRODUCTION}

Soil properties are strongly influenced by five factors: parent material, climate, relief, organisms, and time (Jenny, 1994). Generally, soil A and B horizons formed under aerobic conditions are magnetically enhanced due to the neoformation of ultra fine-grained $(<100 \mathrm{~nm}$, usually spanning the superparamagnetic, SP, and single domain, SD) ferrimagnets (magnetite and/or maghemite), and thus most often, a positive correlation is found between soil magnetism and some climatic factors (e.g., rainfall and temperature; Mullins, 1977; Maher, 1986, 1998).

However, how magnetic iron oxides respond to pedogenesis is still a matter of debate. So far, several mechanisms have been proposed to interpret magnetic enhancement for (paleo) soils, such as the biotic (Lovley et al., 1987; Fassbinder et al., 1990) or fermentation mechanism (Le Borgne, 1955; Mullins, 1977). Later, studies showed that neoformation of pedogenic ferrimagnetic minerals are mainly controlled by a series of abiotic reactions (Maher and Taylor, 1988; Dearing et al., 1996; Torrent et al., 2006). More recently, Boyle et al. (2010) established a chemical kinetic model which further confirmed that abiotic reactions should account for most production of ferrimagnetic minerals. However, the exact pathway has not been fully articulated.

One pathway suggested that maghemite was not formed directly, but through oxidation of magnetite (Dearing et al., 1996; Maher, 1998). By integrating different conceptual models with existing experimental and field data, Boyle et al. (2010) suggested a comprehensive mechanism 
that hydrous ferric oxide could either transform directly to hematite and goethite or magnetite which is later oxidized to maghemite. Yang et al. (2013) observed ferrimagnetic inclusions which have been pedogenically formed by weathering of coarsegrained Fe-bearing silicate minerals and thus suggested that the magnetic enhancement in Chinese loess/paleosols is mainly contributed by the $>0.5 \mu \mathrm{m}$ sediment fraction.

Alternatively, the ferrihydrite $\rightarrow$ maghemite-like phase $\rightarrow$ hematite pathway was proposed (Barrón and Torrent, 2002; Barrón et al., 2003; Cabello et al., 2009) on the basis of experiments in which ferrihydrite doped with some ligands (e.g., phosphate or citrate) was aged at different temperatures. Recently, Michel et al. (2010) revealed that this maghemite-like phase is ordered ferrihydrite with strong magnetism, which can be further evolved into maghemite with grain growing from SP to SD size before its transformation into hematite (Liu et al., 2008; Michel et al., 2010; Barrón et al., 2012). This model was also supported by the linear relationship between concentration of hematite and pedogenic maghemite (Torrent et al., 2006, 2007, 2010a,b). Hu et al. (2013) adopted a novel approach by integrating rock magnetism, dynamic dissolution, and diffuse reflectance spectroscopy techniques on classic Chinese loess. Their results indicated that pedogenic maghemite was initially produced, gradually grew in grain size and eventually formed SD hematite, which produces the first direct piece of evidence for natural records on the ferrihydrite $\rightarrow$ maghemite-like phase $\rightarrow$ hematite pathway. Nevertheless, there is still lacking of natural evidence to directly link the natural observations to Barrón et al. (2003) model because of the complexity of natural environment and effects of magnetic minerals present in the soils parent materials (Hu et al., 2013).

Early studies on soils developed on calcarenites of Neogene age in southern Spain suggested that these soils could be ideal media to test the pedogenic pathway because the father materials are hematite-free and relatively homogeneous, allowing thus the establishment of simple chemical and mineralogical balances (Torrent and Cabedo, 1986; Torrent et al., 2010a). In contrast, other studies claimed that as the world's largest dust source, the Sahara-Sahel corridor in North Africa generates vast amounts of dust annually, which can be transported over long distances westnorthwards to the Canary Island (Lázaro et al., 2008), the North Atlantic (Carlson and Prospero, 1972; Prospero and Carlson, 1972; Chester et al., 1979), the South American continent (Swap et al., 1992), and northward into the eastern Mediterranean (Yaalon and Ganor, 1979; Ganor and Mamane, 1982; Ganor, 1991), the western Mediterranean (Chester et al., 1984; LoyePilot et al., 1986; Loye-Pilot and Morelli, 1988; Bergametti et al., 1989a,b; Larrasoaña et al., 2015), southern Europe (Prodi and Fea, 1979), and mainland Europe (Prospero et al., 1981; Karyampudi et al., 1999; Zhang and Pennington, 2004; Moreno et al., 2005). The distance between Spain and the central Sahara is $<2000 \mathrm{~km}$, and thus should be an important region to deposit the Sahara dust. Previous studies have shown that aeolian dust originated from Northern Africa (mainly including the north and west Sahara, and Sahel region) contributes significantly to Mediterranean soils (Yaalon et al., 1966; Yaalon and Dan, 1967; Yaalon and Ganor, 1973; Macleod, 1980; Driese et al., 2003; Erel

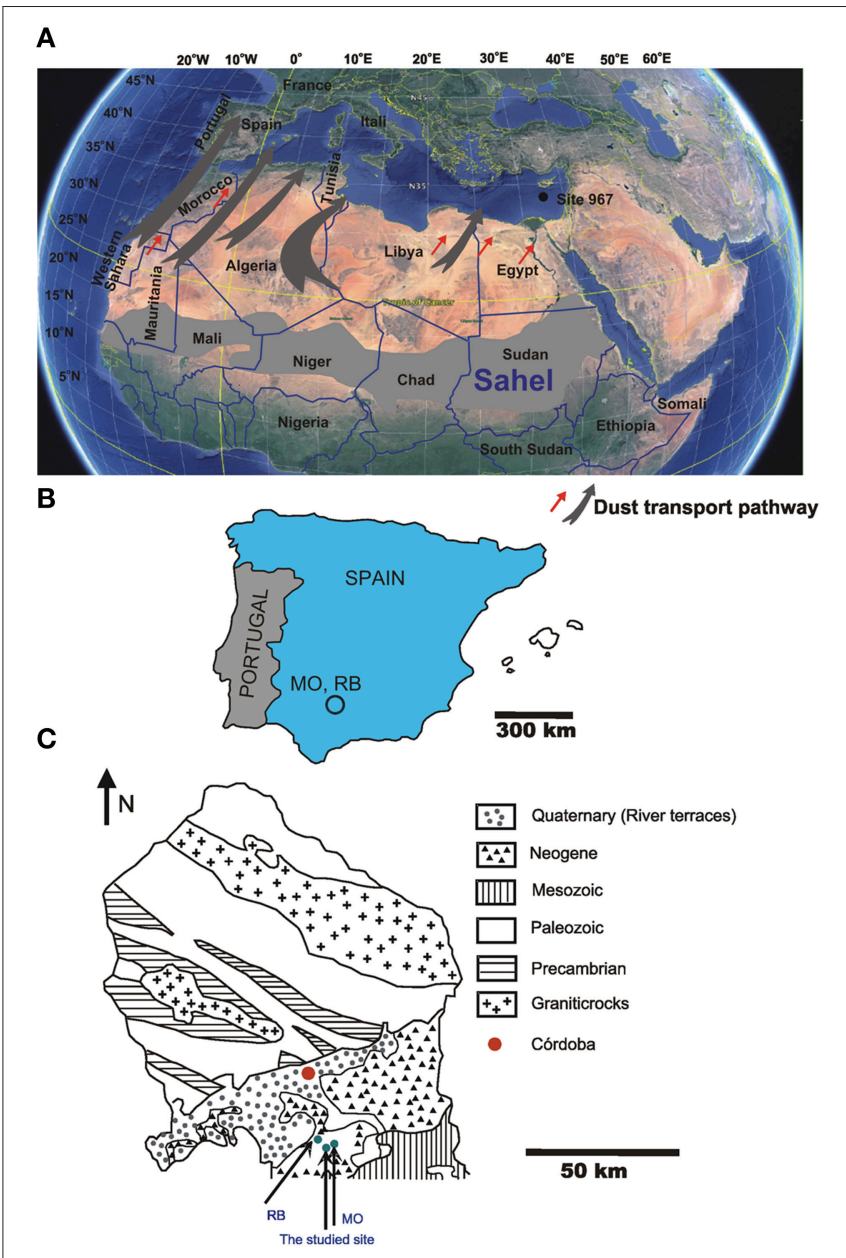

FIGURE 1 | Generalized maps showing the Sahara-Sahel Dust corridor (revised from Google Earth) (A), soil site locations (B), and the main geological unit of the study area. Red arrows in (A) indicate the dust transport pathways from Larrasoaña et al. (2015) for western Africa and Avila et al. (1997) for the eastern Africa, respectively. Gray arrows indicate the main routes of dust outbreaks toward Mediterranean and continental Europe (Guerzoni et al., 1997) (B,C) are revised from Erel and Torrent (2010). The shaded area in (A) indicates the Sahel region (data from https://en.wikipedia. org/wiki/Sahel). RB and $\mathrm{MO}$ indicate site locations respectively in the vicinity of La Rambla and Montilla, Province of Córdoba, southern Spain (Torrent and Cabedo, 1986).

and Torrent, 2010), but contributions of aeolian material to the magnetic enhancement of Spanish soils are unknown.

This study will revisit the Spanish soil to determine major factors affecting the soil magnetism. Specifically, we will systematically conduct both magnetic and non-magnetic experiments to establish the correlation between iron oxides and geochemical elements and clay minerals.

\section{SAMPLING AND METHODS}

\section{Sampling}

This study area is located in the Guadalquivir Basin, an ENEWSW-elongated depression filled with Neogene sediments in 
TABLE 1 | Summary of properties for the studied soils and for relevant material from Sahara-Sahel and Southern China.

\begin{tabular}{|c|c|c|c|c|c|c|c|c|c|}
\hline Samples & H1 & $\mathrm{H} 2$ & H3 & H4 & H5 & Sahara & Sahel & North-West Africa & Red Earth in Southern China \\
\hline Depth (cm) & $100-140$ & $70-100$ & $45-70$ & $20-45$ & $0-20$ & & & & \\
\hline Horizons & Ck & BCk1 & Bt2 & Bt1 & A & & & & \\
\hline$\chi_{L}\left(10^{-8} \mathrm{~m}^{3} \mathrm{~kg}^{-1}\right)$ & 1.07 & 5.49 & 24.17 & 14.68 & 28.3 & $<1.25$ & $<28$ & & $98.8 \pm 36.5$ \\
\hline$\chi_{\mathrm{fd}}\left(10^{-8} \mathrm{~m}^{3} \mathrm{~kg}^{-1}\right)$ & 0.58 & 1.25 & 5.54 & 3.03 & 6.1 & $<0.25$ & $<1.7$ & & $\sim 10$ \\
\hline$M_{s}\left(10^{-3} \mathrm{Am}^{2} \mathrm{~kg}^{-1}\right)$ & 1.05 & 2.12 & 9.42 & 0.49 & 8.21 & & & & \\
\hline $\mathrm{Mrs}_{\mathrm{rs}}\left(10^{-3} \mathrm{Am}^{2} \mathrm{~kg}^{-1}\right)$ & 0.24 & 0.16 & 1.4 & 0.41 & 0.77 & & & & \\
\hline $\operatorname{SIRM}\left(10^{-3} \mathrm{Am}^{2} \mathrm{~kg}^{-1}\right)$ & 0.06 & 0.17 & 0.55 & 0.26 & 0.48 & $<0.15$ & $<2.5$ & & $5.7 \pm 1.5$ \\
\hline $\operatorname{HIRM}\left(10^{-5} \mathrm{Am}^{2} \mathrm{~kg}^{-1}\right)$ & 0.37 & 0.85 & 2.57 & 3.84 & 3.83 & $<0.7$ & $<3.5$ & & \\
\hline $\operatorname{ARM}\left(10^{-5} \mathrm{Am}^{2} \mathrm{~kg}^{-1}\right)$ & 0.07 & 0.79 & 3.05 & 1.14 & 2.54 & & & & $11.7 \pm 1.4$ \\
\hline Smectite (\%) & 84 & 88 & 77 & 48 & 49 & & & & \\
\hline Illite (\%) & 14 & 10 & 16 & 27 & 26 & & & $45-52$ & \\
\hline Kaolinite (\%) & 2 & 2 & 7 & 25 & 25 & & & $24-29$ & \\
\hline $\mathrm{I} / \mathrm{K}$ & 7.9 & 5.1 & 2.4 & 1.1 & 1.0 & 〜2.0 (NS) 0.5 (SC) & 0.1 & $\sim 2$ & \\
\hline $\mathrm{Fe}_{\mathrm{O}}(\mathrm{g} / \mathrm{kg})$ & 0.25 & 0.16 & 0.54 & 1.04 & 1.00 & & & & \\
\hline $\mathrm{Fe}_{\mathrm{d}}(\mathrm{g} / \mathrm{kg})$ & 1.73 & 1.86 & 8.56 & 31.12 & 21.70 & & & & \\
\hline $\mathrm{I}_{\mathrm{Hm}}\left(10^{-5}\right)$ & 0 & 3.33 & 21.7 & 36.8 & 42.8 & & & & \\
\hline $\mathrm{P}_{\mathrm{Hm}}(\mathrm{nm})$ & & 537 & 535 & 538 & 540 & & & & \\
\hline $\mathrm{I}_{\mathrm{Gt}}\left(10^{-5}\right)$ & 12.7 & 11.8 & 39.4 & 53.7 & 62.8 & & & & \\
\hline$P_{G t}(n m)$ & 421 & 423 & 423 & 421 & 423 & & & & \\
\hline$H / G$ & 0 & 0.28 & 0.55 & 0.69 & 0.68 & & & & \\
\hline Quartz (Vol\%) & 32.3 & 23.4 & 90.8 & 82.9 & 83.3 & & & & \\
\hline Calcite (Vol\%) & 62.5 & 72.1 & Trace & 3.8 & Trace & & & & \\
\hline Rutile (Vol\%) & 3.3 & 3.6 & 3.3 & 1.5 & 8.7 & & & & \\
\hline Pyrope (Vol\%) & trace & - & trace & trace & - & & & & \\
\hline Perryite (Vol\%) & trace & - & - & - & - & & & & \\
\hline Anhydrite (Vol\%) & trace & trace & 2.3 & - & 1.4 & & & & \\
\hline Orthoclase (Vol\%) & - & - & - & 8.1 & 6.6 & & & & \\
\hline Dolomite (Vol\%) & - & - & trace & 3.1 & - & & & & \\
\hline Allophane/diaspore (Vol\%) & - & - & 1.9 & - & trace & & & & \\
\hline
\end{tabular}

Southern Spain. The soil profile studied in this work is a typical reddish brown (rubified, Munsell hues 5YR or redder) soil, which is located in the vicinity of La Rambla (RB), Province of Córdoba (Figure 1). In this area, the mean annual temperature, and annual rainfall are about $17^{\circ} \mathrm{C}$ and $600 \mathrm{~mm}$, respectively, and the soils parent materials are Tortonian calcareous sandstones [IGME IGME (Instituto Geológico y Minero de España), 1971] with sand occurring mostly in the $0.02-0.2 \mathrm{~mm}$ size fraction. The clay fraction represent $<5 \%$ of the rock and is mainly composed of smectite with rather small proportions of kaolinite, illite, and goethite (Torrent and Cabedo, 1986; Torrent et al., 2010a). The reddish brown soil is classified as Chromic or Calcic Luvisols Calcic (Torrent and Cabedo, 1986). Calcic horizons are present at various depths of the soil profiles. Five representative samples ( $\mathrm{H} 1, \mathrm{H} 2, \mathrm{H} 3, \mathrm{H} 4, \mathrm{H} 5)$ were collected covering A, B, and C horizons. The major properties of these samples are summarized in Table 1.

\section{Magnetic Methods}

The mass-specific magnetic susceptibility $(\chi)$ was measured using a multi-function Kappabridge (MFK-FA) with operating frequencies of 976 and $15616 \mathrm{~Hz}$ in a magnetic field of 200
$\mathrm{Am}^{-1}$. To quantify the magnetically viscous particles near the SP and SD threshold $(\sim 20-25 \mathrm{~nm}$ for magnetite and maghemite; Liu et al., 2012), $\chi_{\mathrm{FD}}$ was calculated $\left(\chi_{\mathrm{FD}}=\chi_{\mathrm{LF}^{-}}\right.$ $\chi_{\text {HF }}$, where $\chi_{\text {LF }}$ and $\chi_{\text {HF }}$ are the susceptibility measured in 976 and $15616 \mathrm{~Hz}$, respectively). In addition, $\chi_{\mathrm{FD}} \%$ is defined as $\chi_{\mathrm{FD}} / \chi_{\mathrm{LF}} \%$. Alternatively, $\chi_{\mathrm{FD}} \%$ can be estimated by linearly fitting to the linear trend from the plot of $\chi_{F D}$ vs. $\chi_{L F}$.

Anhysteretic remanent magnetization (ARM) was imparted with an alternating field (AF) of $100 \mathrm{mT}$ and a superimposed bias DC field of $0.05 \mathrm{mT}$ during the whole experiment. The isothermal remanent magnetization (IRM) was acquired in a forward field of $1 \mathrm{~T}$ using a Model 660 IRM Impulse Remanent Magnetizer (2G Enterprises, USA), after which reverse fields of 100 and $300 \mathrm{mT}$ were applied. The corresponding forward and backfield IRMs are referred to as $\mathrm{IRM}_{1 \mathrm{~T}}, \mathrm{IRM}_{-100 \mathrm{mT}}$, and IRM-300 $\mathrm{mT}$, respectively. The hard fraction of IRM was then calculated as $\mathrm{HIRM}_{300 \mathrm{mT}}=\left(\mathrm{IRM}_{1 \mathrm{~T}}+\mathrm{IRM}_{-300 \mathrm{mT}}\right) / 2$ (Bloemendal et al., 1992). Similarly, HIRM $_{100 \mathrm{mT}}$ is defined as $\mathrm{HIRM}_{100 \mathrm{mT}}=\left(\mathrm{IRM}_{1 \mathrm{~T}}\right.$ $\left.+\mathrm{IRM}_{-100 \mathrm{mT}}\right) / 2 . \mathrm{HIRM}_{300 \mathrm{mT}}$ has been traditionally used as a proxy for high coercivity minerals with remanence coercivity larger than $300 \mathrm{mT}$, such as hematite and goethite (Thompson and Oldfield, 1986). However, in natural samples, hematite and 

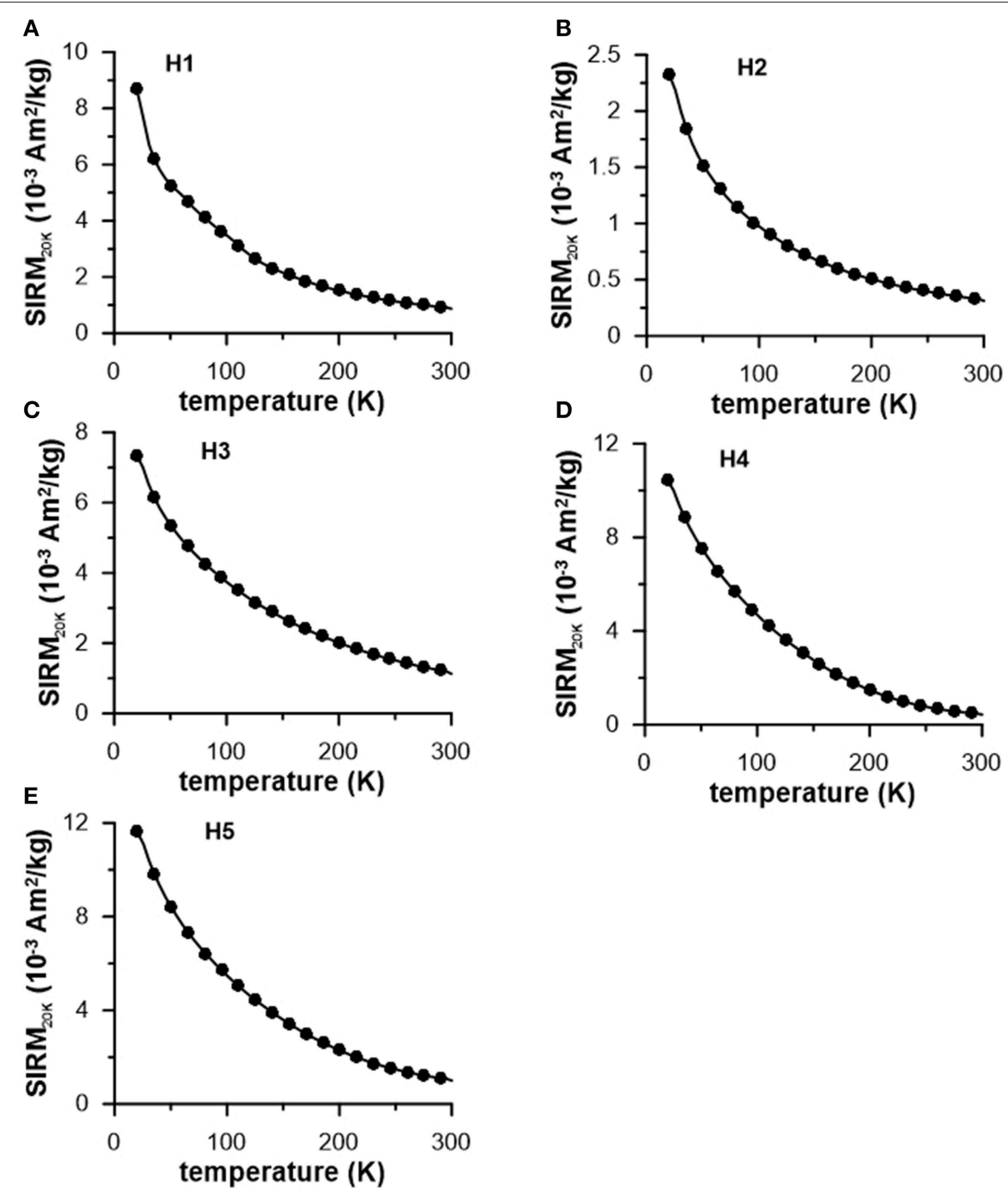

FIGURE 2 | Low temperature thermal demagnetization of SIRM curves acquired at $20 \mathrm{~K}\left(\mathrm{SIRM}_{20} \mathrm{~K}\right)$ for the studied samples, (A) H1, (B) H2, (C) H3, (D) H4, and (E) H5.

goethite are often Aluminum (Al) substituted, which reduces the remanence coercivities of Al-hematite and goethite to lower values (Liu et al., 2007; Jiang et al., 2012, 2014a,b). More recently, $\mathrm{Hu}$ et al. (2013) put forward that the nano-sized hematites of pedogenic origins have remanence coercivity value of about 130 $\mathrm{mT}$. Thus, contributions of pedogenic hematite can be estimated by $\mathrm{HIRM}_{100 \mathrm{mT}}-\mathrm{HIRM}_{300 \mathrm{mT}}$.

Theoretically, HIRM is the remanent magnetization acquired by particles with coercivities of remanence larger than the reverse field (RF) but smaller than the forward field (FF). Thus, a more general definition is $\operatorname{HIRM}_{(\mathrm{FF}, \mathrm{RF})}$ $=\left(\mathrm{IRM}_{\mathrm{FF}}+\mathrm{IRM}_{\mathrm{RF}}\right) / 2$. Correspondingly, $\mathrm{HIRM}_{(\mathrm{FF} 1, \mathrm{RF} 1)^{-}}$ $\operatorname{HIRM}_{(\mathrm{FF} 1, \mathrm{RF} 2)}=\operatorname{HIRM}_{(-\mathrm{RF} 2, \mathrm{RF} 1)}$ when RF1 > RF2, which is the difference between two HIRMs measured with the same forward field but with different reverse fields and represents the remanence acquired by particles with coercivities of remanence bounded by the two reverse fields. Similarly, HIRM(FF1, RF1) - $\operatorname{HIRM}_{(\mathrm{FF} 2, \mathrm{RF} 1)}=\operatorname{HIRM}_{(\mathrm{FF} 1,-\mathrm{FF} 2)}$ when FF1 > FF2. This definition gives HIRM wider applicability when particles have a more complex coercivity distribution.

Saturation magnetization $\left(\mathrm{M}_{\mathrm{s}}\right)$, saturation remanent magnetization $\left(\mathrm{M}_{\mathrm{rs}}\right)$, coercivity $\left(\mathrm{B}_{\mathrm{c}}\right)$, and remanent coercivity $\left(\mathrm{B}_{\mathrm{cr}}\right)$ were measured using a Princeton Measurements Corporation vibrating sample magnetometer (Micromag VSM 3900) after correcting for the paramagnetic contribution. In addition, high resolution First-order reversal curve (FORC) diagrams were measured with Micromag VSM 3900. For each sample, 514 FORCs were measured with a field step of $0.4 \mathrm{mT}$; data were processed using the algorithm of Heslop and Roberts (2012) with a smoothing factor of 5 .

The temperature dependence of SIRM was measured in the range of $20-300 \mathrm{~K}$ to investigate the magnetic minerals 

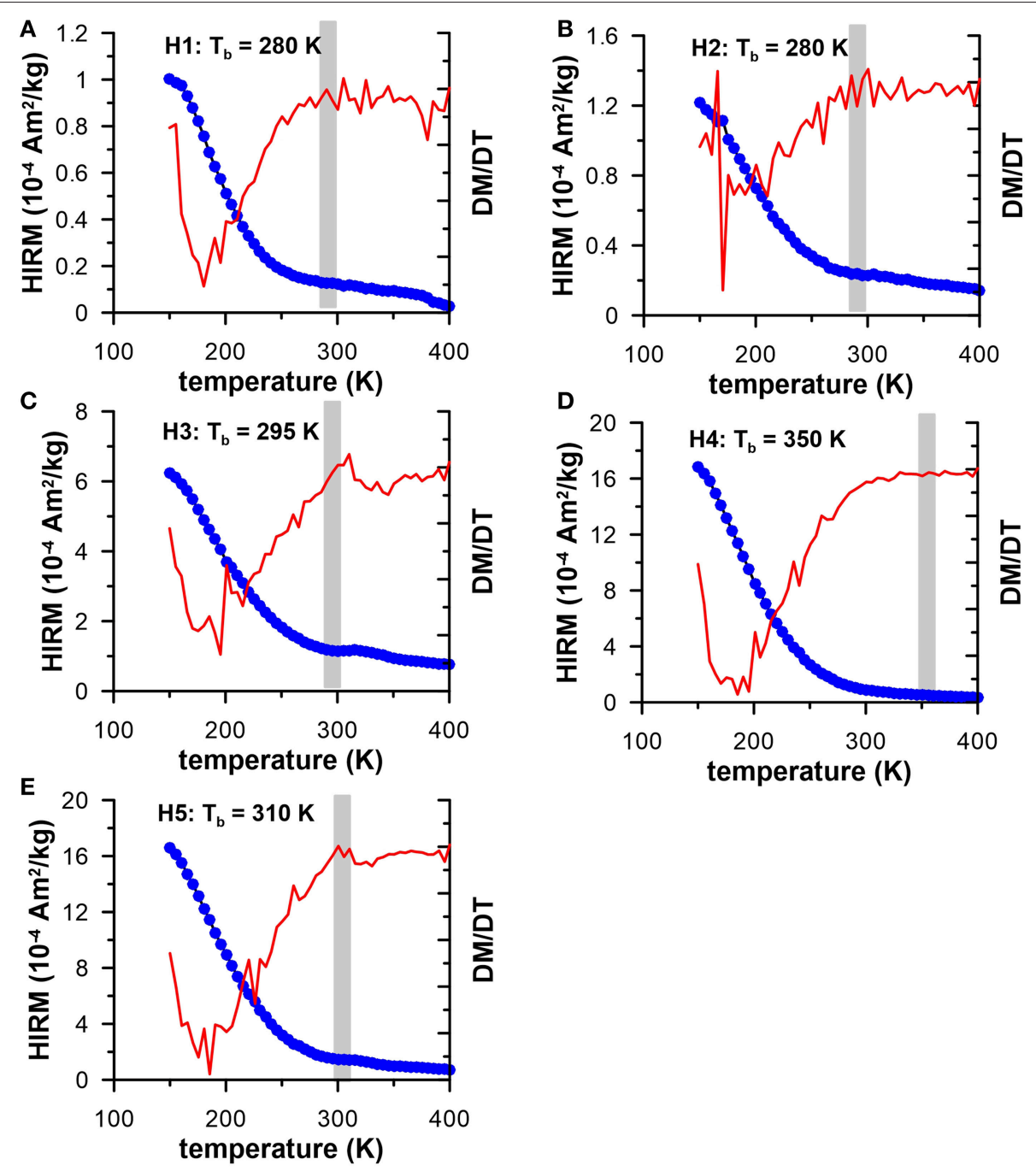

FIGURE 3 | Low temperature thermal demagnetization of HIRM curves for the studied samples, (A) H1, (B) H2, (C) H3, (D) H4, and (E) H5, where blue solid circle and red line represent HIRM curves and their first derivative curves, respectively. The shaded area indicates the blocking temperature of goethite.

of samples. Firstly, samples were cooled to $20 \mathrm{~K}$ at a zero field, then $S_{2 R M} 2 \mathrm{~K}$ were imparted in a $5 \mathrm{~T}$ field, after the switch-off of field, SIRM $_{20 \mathrm{~K}}$ was measured from 20 to 300 $\mathrm{K}$ using a Quantum Design magnetic properties measurement system (MPMS XL-5, with sensitivity of $5.0 \times 10^{-10} \mathrm{Am}^{2}$ ). Since haematite in natural samples is almost saturated at $2.5 \mathrm{~T}$ field, for this study, HIRM is redefined as $\left(\mathrm{SIRM}_{5 \mathrm{~T}}+\mathrm{IRM}_{-2.5 \mathrm{~T}}\right) / 2$. To avoid the disturbance of the Verwey transition of magnetite $(\sim 120 \mathrm{~K})$, the temperature dependence of HIRM were measured from 150 to $400 \mathrm{~K}$ to investigate the information of exist goethite (Jiang et al., 2014a). First, samples were cooled from the room temperature to $150 \mathrm{~K}$ in a zero field, and then SIRM $_{5 \mathrm{~T}}$ was imparted with $5 \mathrm{~T}$ field. After the magnetic field was switched off, SIRM $_{5 \mathrm{~T}}$ was measured from 150 to $400 \mathrm{~K}$. The curve is defined as $\operatorname{SIRM}_{5 \mathrm{~T}}(\mathrm{~T})$. After that, samples were cooled to $150 \mathrm{~K}$ in a zero field again, and then IRM $_{-2.5 \mathrm{~T}}$ was obtained in a $2.5 \mathrm{~T}$ backward field, and was thermally demagnetized from 150 to $400 \mathrm{~K}$. The corresponding curve is termed as IRM-2.5 $\mathrm{T}(\mathrm{T})$. The temperature dependence of HIRM
$(\operatorname{HIRM}(T))$ is calculated by $\left[\operatorname{SIRM}_{5 \mathrm{~T}}(T)+\operatorname{IRM}_{-2.5 \mathrm{~T}}(T)\right] / 2$. The Low temperature dependence of susceptibility curves were also measured at two frequencies $(1,10$, and $100 \mathrm{~Hz})$ from 10 to 300 $\mathrm{K}$ using MPMS. For the low temperature measurements, $\chi_{\mathrm{FD}}$ is defined as $\chi_{1 \mathrm{~Hz}}-\chi_{10 \mathrm{~Hz}}$ and $\chi_{1 \mathrm{~Hz}}-\chi_{100 \mathrm{~Hz}}$. The applied alternative field was set to be $0.4 \mathrm{mT}$.

\section{DRS Measurements}

The Diffuse Reflectance spectra (DRS) were recorded by a Cary 5000 UV-VIS-IR spectrophotometer (Varian Inc., Palo Alto, CA) equipped with an integrating sphere accommodating a $\mathrm{PMT} / \mathrm{PbS}$ detector at a scan rate of $30 \mathrm{~nm}$ per minute from $300-2600 \mathrm{~nm}$ in $0.5 \mathrm{~nm}$ steps. Then the reflectance values were transformed into the Kubelka-Munk (K-M) remission function and the bands of the second derivative of the K-M function spectrum at $\sim 425$ and $535 \mathrm{~nm}$ were used to quantitatively estimate the relative mass concentration of goethite and hematite respectively, as described by Torrent and Barrón (2008). 

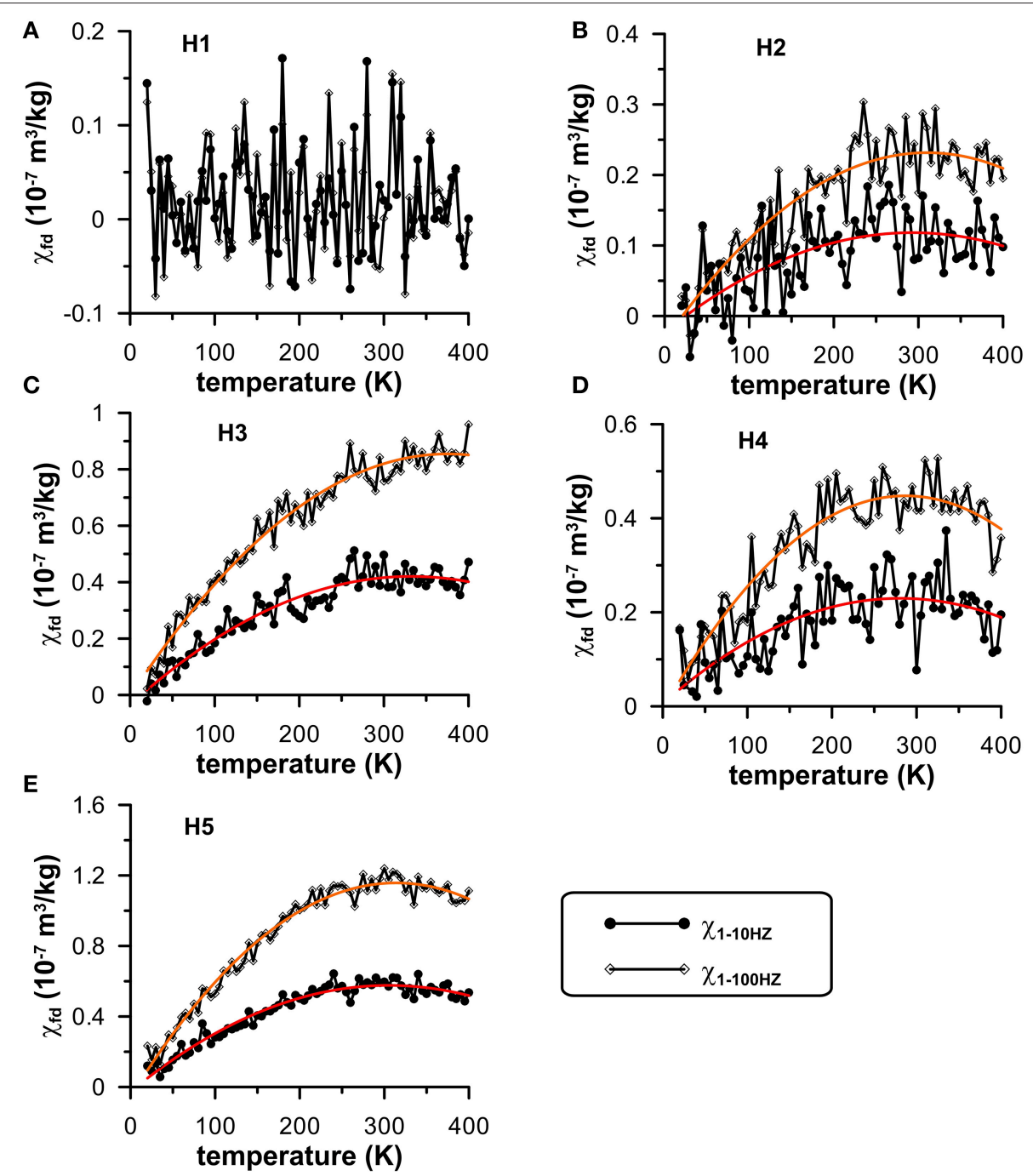

FIGURE 4 | Low temperature dependence of $\chi_{\mathrm{fd}}$ curves for the studied samples, (A) H1, (B) H2, (C) H3, (D) H4, and (E) H5, where solid circles and open diamonds represent $\chi_{\mathrm{fd}}$ determined from $\chi_{1 \mathrm{~Hz}}-\chi_{10 \mathrm{~Hz}}$ and $\chi_{1 \mathrm{~Hz}}-\chi_{100 \mathrm{~Hz}}$, respectively, while red and orange lines indicate the corresponding fitting curves.

\section{Geochemical Analyses}

Trace element compositions were determined using an inductively coupled plasma mass spectrometer (ICP-MS, ElEMENT, Finnigan MAT) at IGGCAS. The samples were digested in $\mathrm{HNO}_{3}$ and $\mathrm{HF}$ (1:1) under high temperature and pressure. Measurement of two certified reference materials (GSR-1 granite and GSR-3 basalt) indicates that analytical uncertainties for all trace elements in this study are $<3 \%$. In this study, REE concentrations were normalized to post-Archean Australian shale (PAAS, indicated by a subscript "P") (Taylor and McLennan, 1985), which has proved to be more effective when comparing REE patterns (Zhang and Pennington, 2004; Ferrat et al., 2011).

\section{XRD Analyses and Clay Minerals}

Bulk mineralogy was analyzed on bulk samples that were ground to $<45 \mu \mathrm{m}$. Clay and bulk mineralogy were analyzed by X-ray diffraction (XRD) using a PANAlytical diffractometer fitted with $\mathrm{CuK} \alpha$-radiation at $40 \mathrm{KV}$ and $40 \mathrm{~mA}$.

Clay minerals were identified on oriented slides of clay-sized $(<2 \mu \mathrm{m})$ particles. The oriented slides were obtained following the methods described in detail by Zhang and Guo (2014). Three XRD runs were performed, following air-drying (AD), ethylene-glycol (eg) solvation, and glycerol (G) solvation. Bulk samples were scanned at a speed of $1^{\circ} / \mathrm{min}$ from 15 to $60^{\circ}$ 20. All samples were identified based on the following peaks: quartz, 4.26 and $3.34 \AA$, calcite, $3.03 \AA$, rutile, $3.25 \AA$, pyrope, $2.58 \AA$, perryite, $2.01 \AA$, anhydrite, $3.49 \AA$, orthoclase, $3.32 \AA$, dolomite, $2.91 \AA$, allophane, $3.30 \AA$, diaspore, $3.98 \AA$. In the case of the coarse fractions, mineral abundances were determined using peak heights. Due to the intensity of the diffraction pattern (generally expressed as peak height or peak area) of a mineral in a mixture is proportional to its concentration, the relative proportions (semi-quantitatively expressed as vol\%) of 

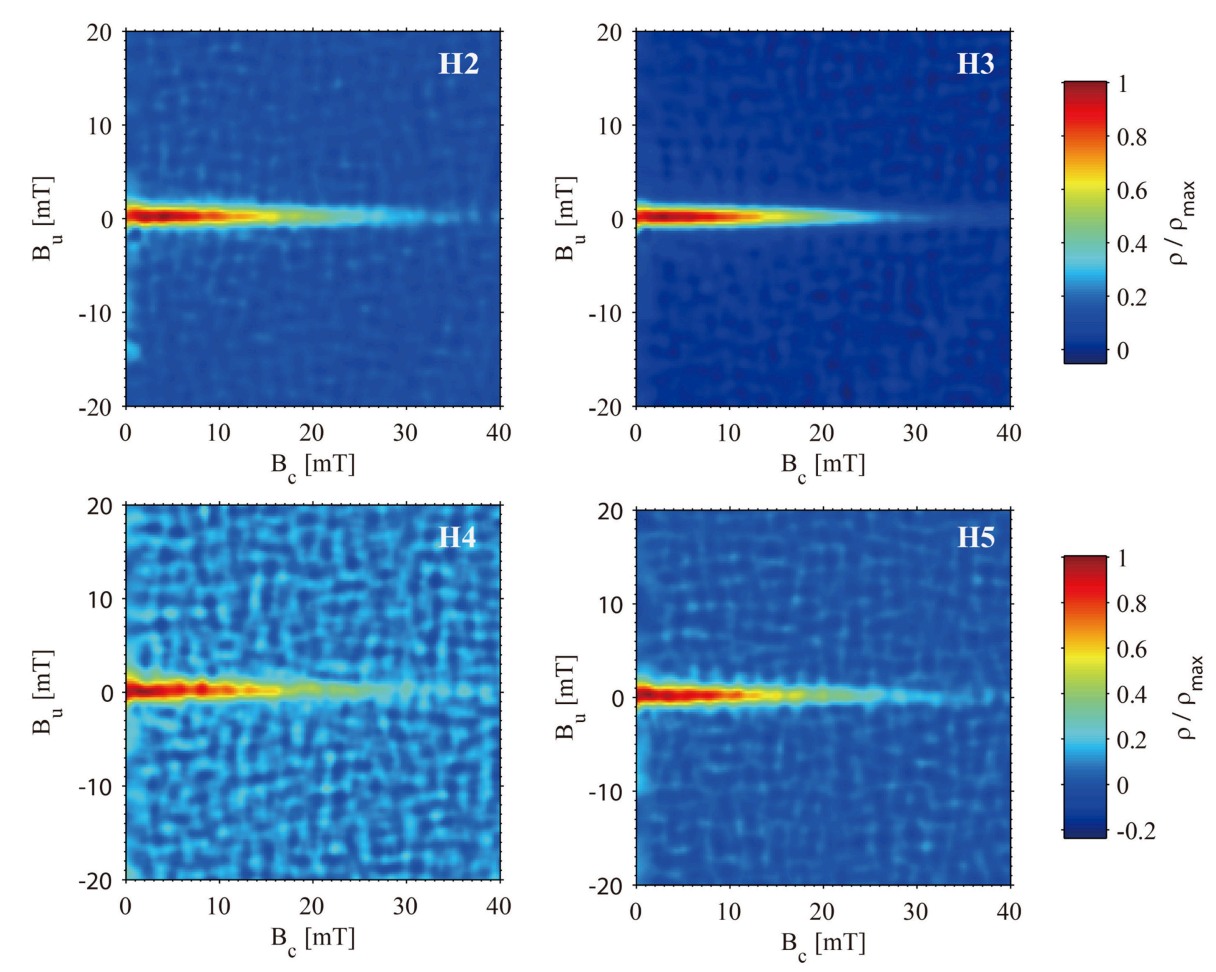

FIGURE 5 | FORC diagrams for the studied samples.

the identified minerals can be roughly determined using their peak intensities by measuring the heights of the main reflections with MacDiff software (Petschick, 2000). The detection limit for quartz is $1 \%$, for calcite is $3 \%$, and for other minerals around $5 \%$.

\section{RESULTS}

Major properties of the studied Spanish soil samples are summarized in Table 1. The Ck horizon (Sample H1) has rather low magnetic properties. Its $\chi$ and $\mathrm{M}_{\mathrm{s}}$ are only $\sim 1 \times 10^{-8}$ $\mathrm{m}^{3} \mathrm{~kg}^{-1}$ and $1 \times 10^{-3} \mathrm{Am}^{2} \mathrm{~kg}^{-1}$, respectively. From the $\mathrm{C}$ horizon to A horizon, all magnetic properties of samples are magnetically enhanced except for the sample $\mathrm{H} 4$ with relatively reduced magnetic properties. This pattern is similar to the one observed for other reddish brown soil profiles of the area (Torrent et al., 2010a).

Low-temperature thermal demagnetization of $\mathrm{SIRM}_{20 \mathrm{~K}}$ curves for the studied samples are shown in Figure 2. With increasing temperature, $\mathrm{SIRM}_{20 \mathrm{~K}}$ gradually decreases due to unblocking of nano-sized magnetic particles from SD state to SP state. A detectable kink at $\sim 120 \mathrm{~K}$ (Verwey transition) for the sample $\mathrm{H} 1$ indicates the presence of magnetite, which is absent for the other samples.

Low-temperature thermal demagnetization of HIRM curves (Figure 3) indicates a major drop in intensity below $250 \mathrm{~K}$. For sample H1, HIRM can be further partially unblocked at $\sim 380 \mathrm{~K}$, which indicates the presence of relatively stoichiometric goethite. But for samples $\mathrm{H} 3-\mathrm{H} 5$, the second intensity unblocking occurred at relatively reduced temperature $(\sim 350 \mathrm{~K})$, which suggests that goethite in these samples is more Al-substituted. The residual HIRM at $400 \mathrm{~K}$ is believed to be carried by hematite. These results are consistent with the presence of both hematite and goethite in similar reddish soils of the area (Torrent and Cabedo, 1986; Torrent et al., 2010a).

Low-temperature dependent $\chi_{\mathrm{fd}}$ curves $\left(\chi_{\mathrm{fd}}-\mathrm{T}\right.$, Figure 4$)$ are sensitive to the grain size distribution of SP particles. With increasing temperature, $\chi_{\mathrm{fd}}$ gradually increases and peaks at $\sim 300-350 \mathrm{~K}$. This indicates that the dominant grain size of nano-sized ferrimagnetic particles in these samples is located at the SP/SD threshold ( $\sim 20-25 \mathrm{~nm}$ for magnetite and maghemite), which is consistent with the results from Chinese paleosols (Liu et al., 2005).

FORC diagrams can be used to indicate both the remanence coercivity distribution and the magnetic interaction field. Clearly, the narrow distribution along the vertical axis indicates rather weakly magnetic interaction (Figure 5). The wide spread of the FORC intensity indicates that magnetic minerals in samples have wide distribution of remanent coercivity.

Identification of clay minerals was made mainly according to the position of the (001) series of basal reflection on the three $\mathrm{XRD}$ diagrams. Compared with the air-dried curve (AD), the eg/G curves have a new peak at 16.2/18.0 $\AA$ and the 14.1 peak disappear in eg and $G$ (Figures 6A-E); the higher-order reflections (002 and 003) of smectite are present in G curve; this implies the occurrence of smectite. Illite can be defined as a claysize material that exhibits a rational series of reflections with a 

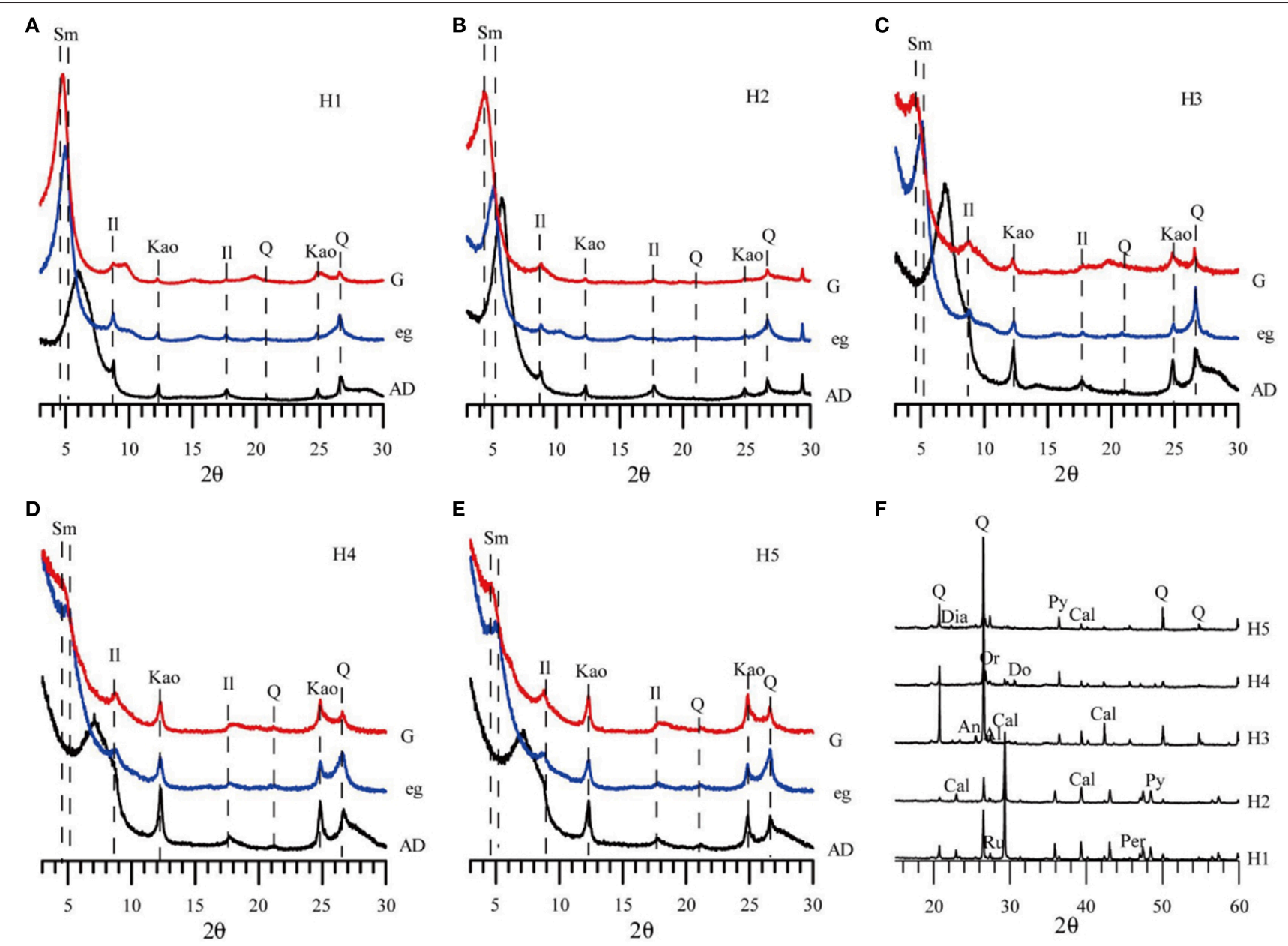

E

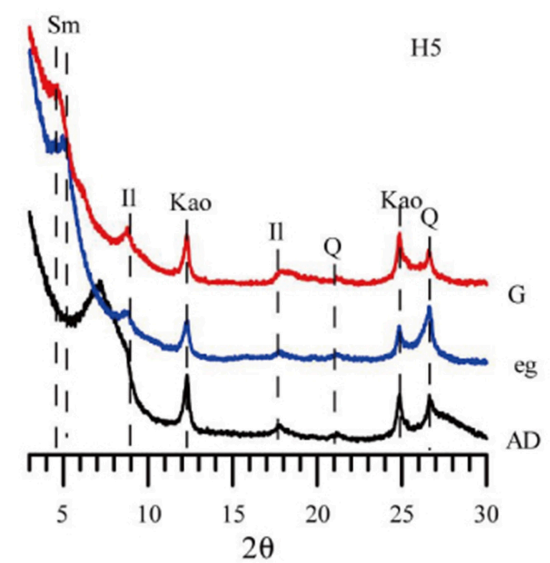

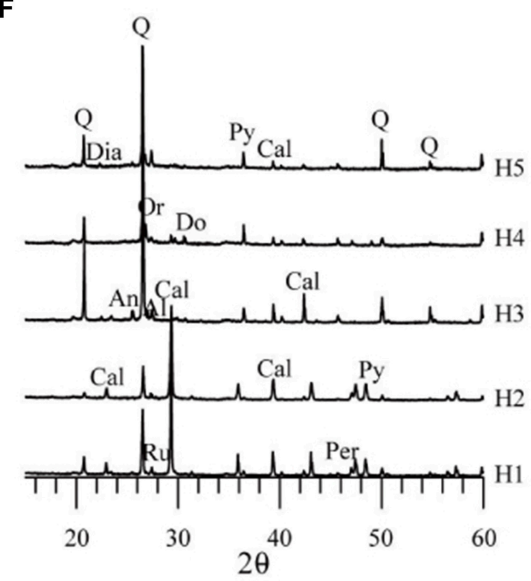

FIGURE 6 | XRD spectra for the studied samples. (A-E) XRD diagrams for $\mathrm{H} 1-\mathrm{H} 5$ to identify their clay minerals. Three XRD runs were performed following air-drying (AD), ethylene-glycol (eg), and glycerol (G) solvation. (F) XRD diagrams used for the quantification of clay minerals in samples $\mathrm{H1}$ - $\mathrm{H} 5$.

d001 spacing of about $10 \AA$ that does not change in ethylene glycol or glycerol saturation (Figures 6A-E). Due to the absent of $14.1 \AA$ peak in eg and G, $7 \AA$, and $3.57 \AA$ peaks in all curves are recognized as kaolinite (Figures 6A-E). Based on the above identifications, the clay minerals in the samples are smectite, illite, and kaolinite. Semi-quantitative estimates of peak area of the basal reflections for the main clay mineral groups of smectite

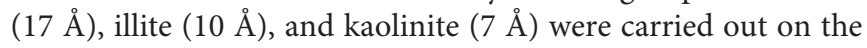
glycolated curve using the MacDiff software (Petschick, 2000) with the weighting factors introduced by Biscaye (1965).

For clay minerals, the parent samples ( $\mathrm{H} 1$ and $\mathrm{H} 2)$ are dominated by smectite $(>80 \%)$ with trace amount of kaolinite $(<2 \%)$. The illite content is $<15 \%$ (Table 1). For the B and C horizons (H3-H5), the smectite content gradually decrease down to $<50 \%$. As shown in Figure $6 \mathbf{F}$ and Table 1 , the quartz content also changes largely from $\mathrm{H} 1$ to H5. For the parent material, the quartz content is about $30 \%$ and then sharply increase up to $>80 \%$ for the A and B horizons. Orthoclase is present only in the A horizon.

Correlations among magnetic and non-magnetic parameters are summarized in Figure 7. The parent material $\mathrm{H} 1$ and $\mathrm{H} 2$ has the highest smectite content $(>90 \%)$. With increasing degree of pedogenesis, smectite content decreases, and illite and kaolinite contents increase (Figure $7 \mathrm{~A}) \cdot \chi$ is positively correlated with $\chi_{\mathrm{fd}}$ and ARM $\left(R^{2}=0.99\right)$, which indicates that the enhancement of bulk $\chi$ is caused by the neoformation of nano-sized particles (Figures 7B,C). HIRM (>300 mT) and HIRM (>100 mT) are carried by hematites with different coercivity distributions. The linear correlation between these two parameters strongly indicates that hematites in these samples have rather stable properties (Figure 7D; Liu et al., 2012). HIRM (100 mT, $300 \mathrm{mT}$ ) has been demonstrated to be strongly related to hematites of pedogenic origin (Hu et al., 2013).

\section{DISCUSSION AND CONCLUSIONS}

On the basis of the concentration of incompatible elements (REE, $\mathrm{Nb}, \mathrm{Ta}, \mathrm{Zr}, \mathrm{Hf}$; Figure 8) and the corresponding ratios ( $\mathrm{Zr} / \mathrm{Hf}$, $\mathrm{Nb} / \mathrm{Ta}, \mathrm{Eu} / \mathrm{Eu}^{*}$, and $\mathrm{Nb} / \mathrm{La}$; Table 2), samples $\mathrm{H} 3, \mathrm{H} 4$, and $\mathrm{H} 5$ clearly have an origin different from samples $\mathrm{H} 1$ and $\mathrm{H} 2$. The dust source for the Spanish soil can be confined by the wind transportation route. On the basis of the main routes of dust 

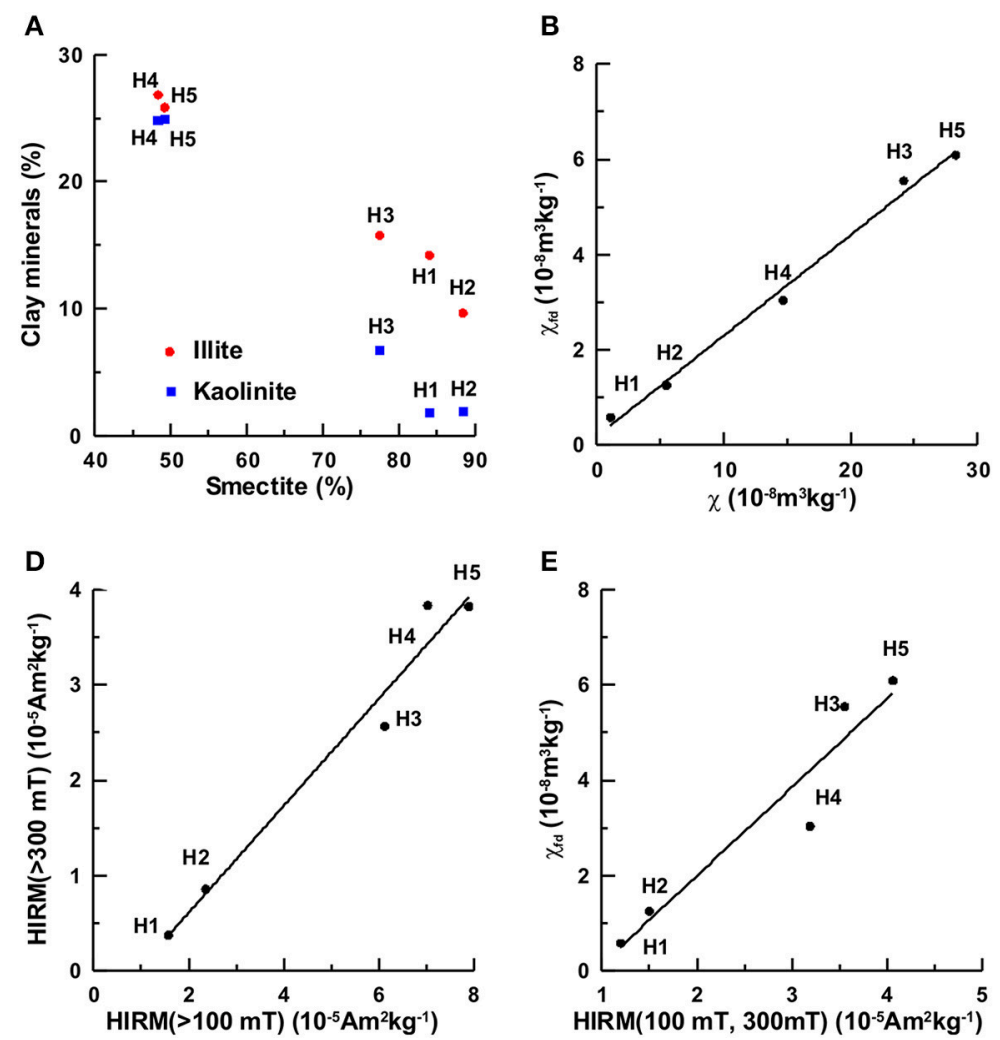

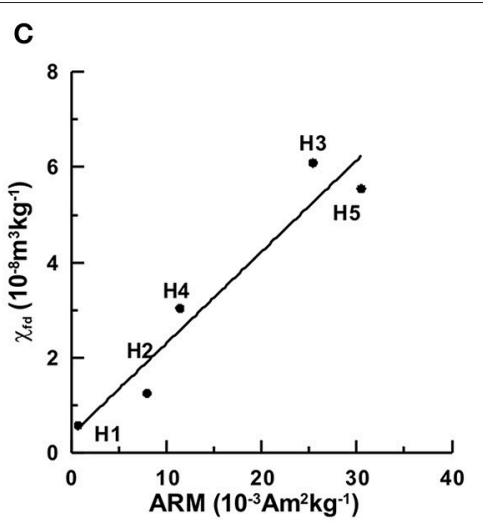

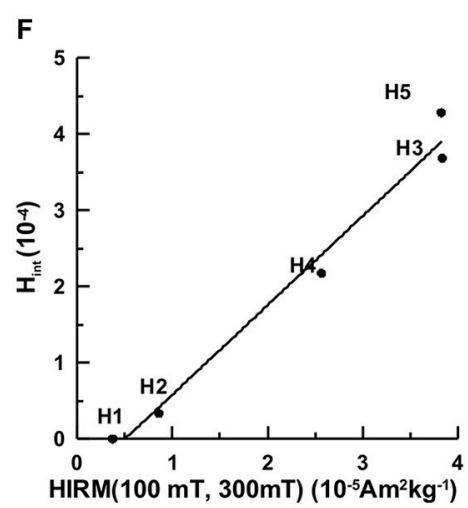

FIGURE 7 | Plots of illite (Kaolinite) vs. Smectite (A), $\chi_{f d}$ vs. $\chi$ (B), $\chi_{f d}$ vs. ARM (C), HIRM (>300 mT) vs. HIRM (>100 mT) (D), $\chi_{f d}$ vs. HIRM (100 mT, 300 mT) (E), and $H_{\text {int }}$ vs. HIRM (100 mT, $300 \mathrm{mT}$ ) (F).

outbreaks toward Mediterranean and continental Europe, the dominant dust material deposited in Spain are originated from the northwest Africa (Guerzoni et al., 1997). Avila et al. (1997) systematically investigated the mineralogical composition of Africa dust over the northeastern Spain. Using the back trajectory analyses, they identified three dust sources in northwest Africa: Western Sahara, Morocan Atlas, and central Algeria.

The dust source for the Spanish soil can be further determined by the geochemical analyses. Kaolinite is the low-latitude clay mineral, and its concentration gradually increases from high latitude region toward the equator (Griffin et al., 1968; Chester et al., 1972; Caquineau et al., 1998). The sudden increases of the Kaolinite concentration for samples H4 and H5 indicates that material for these two samples originated from places with latitudes lower than that of the studied site. Illite is formed under a wide variety of geological conditions, but becomes dominant at higher latitude when contributions of kaolinite become weak (Griffin et al., 1968; Chester et al., 1972; Caquineau et al., 1998). Caquineau et al. (1998) systematically investigated the clay ratios for samples from the Sahara desert and the Sahel. Their results showed that I/K ratio were the highest $(\sim 2.0)$ for dust from the north and east Sahara. In contrast, the $\mathrm{I} / \mathrm{K}$ ratio approaches to $\sim 0.1$ for samples from the Sahel. Samples from the south and central Sahara have a $\mathrm{I} / \mathrm{K}$ ratio of $\sim 1.0$. In our soil, $\mathrm{I} / \mathrm{K}$ is $>1.0$ throughout the profile, which certainly excludes the Sahel as the major dust source. Then Sahara will be the most possible sources for the Aeolian dust to the studied region.

Magnetic properties of the Sahara dust have been welldetermined by Lyons et al. (2010). They observed that concentration-dependent magnetic proxies ( $\chi$, ARM, SIRM) of the Sahara dust gradually increase toward the equator. This significant north-to-south gradients in magnetic mineral concentrations is compatible with a progressive wetter climate across the Sahara/Sahel transect from north to south. This strongly indicate that the formation of magnetic minerals through pedogenesis is strongly controlled by local climate, typically annual amount of precipitation. Although, Sahel dust has enhanced concentration-dependent magnetic properties because of the stronger degree of pedogenesis, they do not significantly contribute to the magnetism of Spanish soils. Concentration-dependent of magnetic properties of Sahara dusts, especially from the northern Sahara are rather low because of the low mean annual precipitation $(<200 \mathrm{~mm} / \mathrm{yr})$, and are comparable to these of the bed rock samples from the Spanish soil profile. This strongly indicates that the initial inputs of magnetic minerals in the Sahara dust do not account for the largely magnetic enhancement for samples from the $\mathrm{A}+\mathrm{B}$ horizons.

Previous studies have shown that rain events in Spain sporadically contain a reddish residual (know as red rains; Avila et al., 1997). Therefore, hematite could be inherited from the 

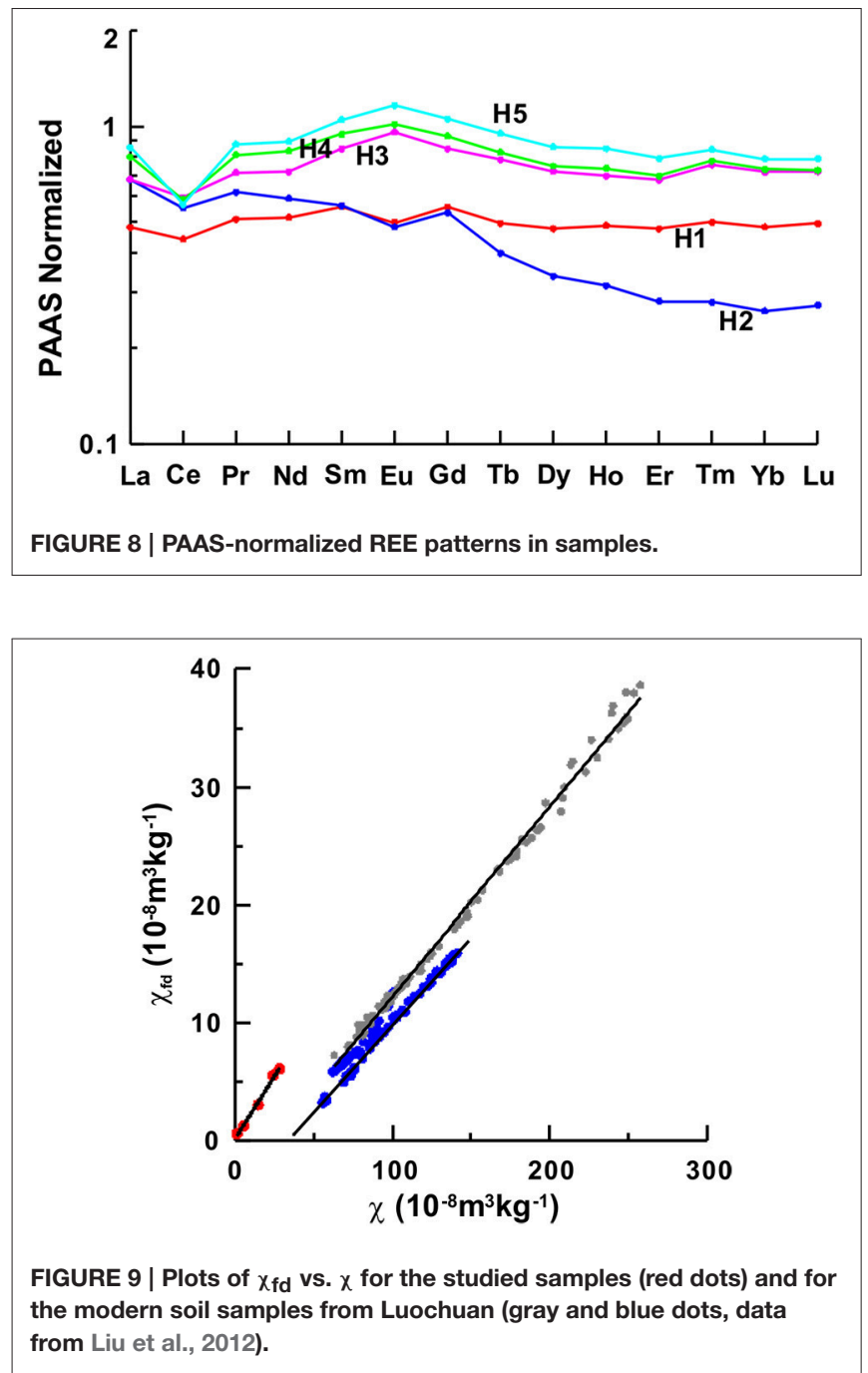

Sahara dust. Nevertheless, we believe that hematite content of Sahara origin in the studied soil is rather limited since the frequency of red rains is too sporadic. This can be further attested by our new rock magnetic studies. Hematite formed in different environment should have different magnetic properties between the different degrees of Al-substitutions. However, our data shows that magnetic properties for hematite in the studied samples are rather consistent, which indicates a simple origin. The linear correlation between hematite and the nano-sized maghemite for the studied samples strongly indicate that these hematites are dominantly of pedogenic origin.

Therefore, the only mechanism for the largely enhancement of concentration-dependent of magnetic properties of the A and B horizons are due to the in-situ formation of pedogenic ferrimagnets. This can be strongly supported by the linear correlation between $\chi_{f d}$ and $\chi$ for the studied soils (Figure 9). This phenomenon has been observed for soils from Argentina and the Chinese Loess Plateau (Liu et al., 2012). The positive correlation between HIRM $(100,300 \mathrm{mT}$; indicator of pedogenic hematite) and $\chi_{\mathrm{fd}}$ (indicator of pedogenic maghemite) further indicates that both nano-sized hematite and mahemite are
TABLE 2 | Trace (ppm) element analyses.

\begin{tabular}{|c|c|c|c|c|c|}
\hline Element & H1 & $\mathrm{H} 2$ & H3 & H4 & H5 \\
\hline $\mathrm{Li}^{*}$ & 11.7 & 10.3 & 26.3 & 35.3 & 34.4 \\
\hline $\mathrm{Be}^{*}$ & 0.6 & 0.6 & 2.0 & 2.8 & 2.7 \\
\hline Sc & 2.2 & 2.0 & 6.7 & 10.3 & 9.3 \\
\hline$V^{*}$ & 15.9 & 16.5 & 56.2 & 96.7 & 96.2 \\
\hline $\mathrm{Cr}^{*}$ & 15.7 & 15.9 & 37.7 & 69.2 & 69.4 \\
\hline Co & 1.8 & 2.0 & 6.0 & 7.3 & 7.3 \\
\hline $\mathrm{Ni}^{*}$ & 2.3 & 12.5 & 23.9 & 30.0 & 29.6 \\
\hline $\mathrm{Cu}^{*}$ & 2.2 & 6.6 & 14.9 & 16.6 & 18.5 \\
\hline $\mathrm{Zn}^{*}$ & 12.8 & 10.6 & 35.2 & 50.1 & 51.0 \\
\hline $\mathrm{Ga}$ & 4.4 & 4.2 & 11.5 & 18.5 & 18.1 \\
\hline $\mathrm{Rb}^{*}$ & 72.5 & 58.4 & 130.9 & 122.0 & 121.2 \\
\hline Sr & 108.0 & 85.9 & 57.6 & 52.3 & 51.9 \\
\hline$Y$ & 13.0 & 8.8 & 18.1 & 18.3 & 21.6 \\
\hline $\mathrm{Zr}$ & 352.2 & 192.8 & 384.1 & 243.8 & 232.4 \\
\hline $\mathrm{Nb}$ & 4.0 & 3.1 & 8.2 & 10.2 & 10.0 \\
\hline Cs & 2.5 & 2.3 & 6.3 & 8.5 & 8.3 \\
\hline $\mathrm{Ba}^{*}$ & 208.1 & 171.0 & 344.4 & 318.6 & 309.3 \\
\hline La & 18.3 & 25.9 & 26.0 & 30.6 & 32.7 \\
\hline $\mathrm{Ce}$ & 35.1 & 44.0 & 47.5 & 46.8 & 45.2 \\
\hline $\operatorname{Pr}$ & 4.5 & 5.5 & 6.3 & 7.2 & 7.7 \\
\hline $\mathrm{Nd}$ & 17.5 & 20.1 & 24.3 & 28.4 & 30.3 \\
\hline $\mathrm{Sm}$ & 3.1 & 3.1 & 4.7 & 5.2 & 5.8 \\
\hline $\mathrm{Eu}$ & 0.5 & 0.5 & 1.0 & 1.1 & 1.3 \\
\hline $\mathrm{Gd}$ & 2.6 & 2.5 & 4.0 & 4.3 & 4.9 \\
\hline $\mathrm{Tb}$ & 0.4 & 0.3 & 0.6 & 0.6 & 0.7 \\
\hline Dy & 2.2 & 1.6 & 3.4 & 3.5 & 4.0 \\
\hline $\mathrm{Ho}$ & 0.5 & 0.3 & 0.7 & 0.7 & 0.8 \\
\hline $\mathrm{Er}$ & 1.4 & 0.8 & 1.9 & 2.0 & 2.3 \\
\hline $\mathrm{Tm}$ & 0.2 & 0.1 & 0.3 & 0.3 & 0.3 \\
\hline $\mathrm{Yb}$ & 1.4 & 0.7 & 2.0 & 2.1 & 2.2 \\
\hline Lu & 0.2 & 0.1 & 0.3 & 0.3 & 0.4 \\
\hline $\mathrm{Hf}$ & 9.4 & 5.1 & 10.4 & 6.8 & 6.4 \\
\hline $\mathrm{Ta}^{*}$ & 0.4 & 0.3 & 0.7 & 0.8 & 0.8 \\
\hline $\mathrm{TI}^{\star}$ & 0.4 & 0.3 & 0.7 & 0.8 & 0.8 \\
\hline $\mathrm{Pb}$ & 12.9 & 10.7 & 25.3 & 29.6 & 30.3 \\
\hline $\mathrm{Bi}^{*}$ & 0.1 & 0.1 & 0.2 & 0.3 & 0.3 \\
\hline Th & 6.3 & 9.5 & 8.9 & 12.6 & 11.9 \\
\hline$U$ & 1.5 & 0.9 & 1.4 & 1.2 & 1.3 \\
\hline
\end{tabular}

${ }^{*}$ indicates the measurement error for this element exceeds $1 \%$.

produced through the same pedogenic processes (Figure 7E). Figure $7 \mathrm{~F}$ shows the correlation between DRS band intensity $\mathrm{H}_{\text {int }}$ for hematite and HIRM $(100,300 \mathrm{mT})$. The positive correlation between these two proxies strongly indicates that variations in HIRM $(100,300 \mathrm{mT})$ are due to changes in hematite concentration rather than its coercivity.

The X-axis intercept is a good indicator for the magnetic properties of parent material without pedogenic alterations $\left(\chi_{\mathrm{fd}}=0\right.$; Liu et al., 2012). Therefore, it is clear that the $\mathrm{X}$-axis intercept for the Luochuan samples are much larger than that of the Spanish soil. This strongly indicates that the parent material of the Spanish soil is basically free of ferrimagnetic minerals 
because the linear trend almost runs through the original point and thus contributes little to the soil magnetic enhancement.

In summary, the material of the $\mathrm{A}$ and $\mathrm{B}$ horizons for the studied Spanish soil appears to be mainly inherited from the Northwestern Africa. However, the magnetic enhancement with limited contributions from the aeolian inputs. This indicates that the magnetism of the Spanish soils still bears significant paleoclimatic signals although the origin of material is complicated.

\section{AUTHOR CONTRIBUTIONS}

QL, JT, VB designed the study and collected samples. $\mathrm{CZ}, \mathrm{PH}, \mathrm{ZJ}$, and ZD conducted experiments. QL, JT,

\section{REFERENCES}

Avila, A., Queralt-Mitjans, I., and Alarcón, M. (1997). Mineralogical composition of African dust delivered by red rains over northeastern Spain. J. Geophys. Res. 102, 21977-21996.

Barrón, V., and Torrent, J. (2002). Evidence for a simple pathway to maghemite in Earth and Mars soils. Geochim. Cosmochim. Acta 66, 2801-2806. doi: 10.1016/S0016-7037(02)00876-1

Barrón, V., Torrent, J., and de Grave, E. (2003). Hydromaghemite, an intermediate in the hydrothermal transformation of 2-line ferrihydrite into hematite. Am. Miner. 88, 1679-1688. doi: 10.2138/am-2003-11-1207

Barrón, V., Torrent, J., and Michel, F. M. (2012). Critical evaluation of the revised akdalaite model for ferrihydrite-Discussion. Am. Miner. 97, 253-254. doi: 10.2138/am.2012.3894

Bergametti, G., Gomes, L., Coudé-Gaussen, G., Rognon, P., and Le Coustumer, M. N. (1989a). African dust observed over Canary Islands: source-regions identification and transport pattern for some summer situations. J. Geophys. Res. 94, 14855-14864.

Bergametti, G., Gomes, L., Remoudaki, E., Desbois, M., Martin, D., and Buat-Ménard, P. (1989b). "Present transport and deposition patterns of African dusts to the north-western Mediterranean," in Paleoclimatology and Paleometeorology: Modern and Past Patterns of Global Atmospheric Transport (Springer), 227-252.

Biscaye, P. E. (1965). Mineralogy and sedimentation of recent deep-sea clay in the Atlantic Ocean and adjacent seas and oceans. Geol. Soc. Am. Bull. 76, 803-832.

Bloemendal, J., King, J., Hall, F., and Doh, S. J. (1992). Rock magnetism of Late Neogene and Pleistocene deep-sea sediments: relationship to sediment source, diagenetic processes, and sediment lithology. J. Geophys. Res. 97, 4361-4375.

Boyle, J. F., Dearing, J. A., Blundell, A., and Hannam, J. A. (2010). Testing competing hypotheses for soil magnetic susceptibility using a new chemical kinetic model. Geology 38, 1059-1062. doi: 10.1130/G31514.1

Cabello, E., Morales, M., Serna, C., Barrón, V., and Torrent, J. (2009). Magnetic enhancement during the crystallization of ferrihydrite at 25 and $50^{\circ} \mathrm{C}$. Clays Clay Miner. 57, 46. doi: 10.1346/CCMN.2009.0570105

Caquineau, S., Gaudichet, A., Gomes, L., Magonthier, M.-C., and Chatenet, B. (1998). Saharan dust: clay ratio as a relevant tracer to assess the origin of soil-derived aerosols. Geophys. Res. Lett. 25, 983-986. doi: 10.1029/98GL00569

Carlson, T. N., and Prospero, J. M. (1972). The large-scale movement of Saharan air outbreaks over the northern equatorial Atlantic. J. Appl. Meteorol. 11, 283-297.

Chester, R., Elderfield, H., Griffin, J., Johnson, L., and Padgham, R. (1972). Eolian dust along the eastern margins of the Atlantic Ocean. Mar. Geol. 13, 91-105.

Chester, R., Griffiths, A., and Hirst, J. (1979). The influence of soil-sized atmospheric particulates on the elemental chemistry of the deep-sea sediments of the northeastern Atlantic. Mar. Geol. 32, 141-154.

Chester, R., Sharples, E., Sanders, G., and Saydam, A. (1984). Saharan dust incursion over the Tyrrhenian Sea. Atmos. Environ. 18, 929-935. and ZJ wrote the paper. All authors contributed to data interpretation and provided significant input to the final manuscript

\section{ACKNOWLEDGMENTS}

This study was supported by the Natural Science Foundation of China (No. 41374073 and 41430962). This work was jointly supported by the National Program on Global Change and Air-Sea Interaction (No. GASI-04-01-02), and Chinese Continental Shelf Deep Drilling Program (GZH201100202). ZJ further acknowledges support from the China Postdoctoral Science Foundation.

Dearing, J., Hay, K., Baban, S., Huddleston, A., Wellington, E., and Loveland, P. (1996). Magnetic susceptibility of soil: an evaluation of conflicting theories using a national data set. Geophys. J. Int. 127, 728-734.

Driese, S. G., Jacobs, J. R., and Nordt, L. C. (2003). Comparison of modern and ancient Vertisols developed on limestone in terms of their geochemistry and parent material. Sediment. Geol. 157, 49-69. doi: 10.1016/S00370738(02)00194-X

Erel, Y., and Torrent, J. (2010). Contribution of Saharan dust to Mediterranean soils assessed by sequential extraction and $\mathrm{Pb}$ and $\mathrm{Sr}$ isotopes. Chem. Geol. 275, 19-25. doi: 10.1016/j.chemgeo.2010.04.007

Fassbinder, J. W. E., Stanjekt, H., and Vali, H. (1990). Occurrence of magnetic bacteria in soil. Nature 343, 161-163.

Ferrat, M., Weiss, D. J., Strekopytov, S., Dong, S., Chen, H., Najorka, J., et al. (2011). Improved provenance tracing of Asian dust sources using rare earth elements and selected trace elements for palaeomonsoon studies on the eastern Tibetan Plateau. Geochim. Cosmochim. Acta 75, 6374-6399. doi: 10.1016/j.gca.2011.08.025

Ganor, E. (1991). The composition of clay minerals transported to Israel as indicators of Saharan dust emission. Atmos. Environ. 25, 2657-2664.

Ganor, E., and Mamane, Y. (1982). Transport of Saharan dust across the eastern Mediterranean. Atmos. Environ. 16, 581-587.

Griffin, J. J., Windom, H., and Goldberg, E. D. (1968). The distribution of clay minerals in the world ocean. Deep Sea Res. Oceanogr. Abstracts 15, 433-459. doi: 10.1016/0011-7471(68)90051-X

Guerzoni, S., Molinaroli, E., and Chester, R. (1997). Saharan dust inputs to the western Mediterranean Sea: depositional patterns, geochemistry and sedimentological implications. Deep Sea Res. Part II 44, 631-654.

Heslop, D., and Roberts, A. P. (2012). Estimation of significance levels and confidence intervals for first-order reversal curve distributions. Geochem. Geophys. Geosyst. 13, Q12Z40. doi: 10.1029/2012gc004115

Hu, P., Liu, Q., Torrent, J., Barrón, V., and Jin, C. (2013). Characterizing and quantifying iron oxides in Chinese loess/paleosols: implications for pedogenesis. Earth Planet. Sci. Lett. 369-370, 271-283. doi: 10.1016/j.epsl.2013.03.033

IGME (Instituto Geológico y Minero de España) (1971). Mapa Geológico de España, E. 1:200.000. CORDOBA; Madrid: Departamento de Publicaciones del IGME.

Jenny, H. (1994). Factors of Soil Formation: A System of Quantitative Pedology. New York, NY: McGraw-Hill.

Jiang, Z., Liu, Q., Barrón, V., Torrent, J., and Yu, Y. (2012). Magnetic discrimination between Al-substituted hematites synthesized by hydrothermal and thermal dehydration methods and its geological significance. J. Geophys. Res. 117, B02102. doi: 10.1029/2011JB008605

Jiang, Z., Liu, Q., Colombo, C., Barrón, V., Torrent, J., and Hu, P. (2014a). Quantification of Al-goethite from diffuse reflectance spectroscopy and magnetic methods. Geophys. J. Int. 196, 131-144. doi: 10.1093/gji/ggt377 
Jiang, Z., Liu, Q., Dekkers, M. J., Colombo, C., Yu, Y., Barrón, V., et al. (2014b). Ferro and antiferromagnetism of ultrafine-grained hematite. Geochem. Geophys. Geosyst. 15, 2699-2712. doi: 10.1002/2014GC005377

Karyampudi, V. M., Palm, S. P., Reagen, J. A., Fang, H., Grant, W. B., Hoff, R. M., et al. (1999). Validation of the Saharan dust plume conceptual model using lidar, Meteosat, and ECMWF data. Am. Meteorol. Soc. 80, 1045-1075.

Larrasoaña, J. C., Roberts, A. P., Liu, Q., Lyons, R., Oldfield, F., Rohling, E. J., et al. (2015). Source-to-sink magnetic properties of NE Saharan dust in Eastern Mediterranean marine sediments: review and paleoenvironmental implications. Front. Earth Sci. 3:19. doi: 10.3389/feart.2015. 00019

Lázaro, F. J., Gutierrez, L., Barrón, V., and Gelado, M. D. (2008). The speciation of iron in: desert dust collected in Gran Canaria (Canary Islands): combined chemical, magnetic and optical analysis. Atmos. Environ. 42, 8987-8996. doi: 10.1016/j.atmosenv.2008.09.035

Le Borgne, E. (1955). Abnormal magnetic susceptibility of the top soil. Ann. Geophys. 11, 399-419.

Liu, Q. S., Barrón, V., Torrent, J., Eeckhout, S., and Deng, C. (2008). Magnetism of intermediate hydromaghemite in the transformation of 2-line ferrihydrite into hematite and its paleoenvironmental implications. J. Geophys. Res. 113, B01103. doi: 10.1029/2007jb005207

Liu, Q. S., Roberts, A. P., Larrasoaña, J. C., Banerjee, S. K., Guyodo, Y., Tauxe, L., et al. (2012). Environmental magnetism: principles and applications. Rev. Geophys. 50, RG4002. doi: 10.1029/2012RG000393

Liu, Q. S., Roberts, A. P., Torrent, J., Horng, C. S., and Larrasoana, J. C. (2007). What do the HIRM and S-ratio really measure in environmental magnetism? Geochem. Geophys. Geosyst. 8, Q09011. doi: 10.1029/2007GC001717

Liu, Q. S., Torrent, J., Maher, B. A., Yu, Y., Deng, C., Zhu, R., et al. (2005). Quantifying grain size distribution of pedogenic magnetic particles in Chinese loess and its significance for pedogenesis. J. Geophys. Res. 110:B11102. doi: 10.1029/2005JB003726

Lovley, D. R., Stolz, J. F., Nord, G. L., and Phillips, E. J. (1987). Anaerobic production of magnetite by a dissimilatory iron-reducing microorganism. Nature 330, 252-254.

Loye-Pilot, M., Martin, J., and Morelli, J. (1986). Influence of Saharan dust on the rain acidity and atmospheric input to the mediterranean. Nature $321,427-428$. doi: $10.1038 / 321427 \mathrm{a} 0$

Loye-Pilot, M., and Morelli, J. (1988). Fluctuations of ionic composition of precipitations collected in Corsica related to changes in the origins of incoming aerosols. J. Aerosol. Sci. 19, 577-585.

Lyons, R., Oldfield, F., and Williams, E. (2010). Mineral magnetic properties of surface soils and sands across four North African transects and links to climatic gradients. Geochem. Geophys. Geosyst. 11, Q08023. doi: 10.1029/2010gc003183

Macleod, D. (1980). The origin of the red Mediterranean soils in Epirus, Greece. J. Soil Sci. 31, 125-136.

Maher, B. (1986). Characterisation of soils by mineral magnetic measurements. Phys. Earth Planet. Inter. 42, 76-92.

Maher, B. A. (1998). Magnetic properties of modern soils and Quaternary loessic paleosols: paleoclimatic implications. Palaeogeogr. Palaeoclimatol. Palaeoecol. $137,25-54$.

Maher, B. A., and Taylor, R. M. (1988). Formation of ultrafine-grained magnetite in soils. Nature 336, 368-370

Michel, F. M., Barrón, V., Torrent, J., Morales, M. P., Serna, C. J., Boily, J. F., et al. (2010). Ordered ferrimagnetic form of ferrihydrite reveals links among structure, composition, and magnetism. Proc. Natl. Acad. Sci. U.S.A. 107, 2787-2792. doi: 10.1073/pnas.0910170107

Moreno, T., Querol, X., Alastuey, A., Viana, M., and Gibbons, W. (2005). Exotic dust incursions into central Spain: implications for legislative controls on atmospheric particulates. Atmos. Environ. 39, 6109-6120. doi: 10.1016/j.atmosenv.2005.06.038

Mullins, C. (1977). Magnetic susceptibility of the soil and its significance in soil science-a review. J. Soil Sci. 28, 223-246.

Petschick, R. (2000). MacDiff chsdateYear1899Month12Day30IsLunarDateFalseIs ROCDateFalse4.2.2. Available online at: http://servermac.geologie.unfrankfurt.de/Rainer.html
Prodi, F., and Fea, G. (1979). A case of transport and deposition of Saharan dust over the Italian peninsula and southern Europe. J. Geophys. Res. 84, 6951-6960.

Prospero, J., Glaccum, R., and Nees, R. (1981). Atmospheric transport of soil dust from Africa to South America. Nature 289, 570-572.

Prospero, J. M., and Carlson, T. N. (1972). Vertical and areal distribution of Saharan dust over the western equatorial North Atlantic Ocean. J. Geophys. Res. $77,5255-5265$.

Swap, R., Garstang, M., Greco, S., Talbot, R., and Kållberg, P. (1992). Saharan dust in the Amazon Basin. Tellus. B. 44, 133-149.

Taylor, S. R., and McLennan, S. M. (1985). The Continental Crust: Its Composition and Evolution. Oxford: Blackwell.

Thompson, R., and Oldfield, F. (1986). Environmental Magnetism. London: Allen. Und. Unwin.

Torrent, J., and Barrón, V. (2008). "Diffuse reflectance spectroscopy," in Methods of Soil Analysis Part 5: Mineralogical Methods, eds A. L. Ulery and R. Drees (Madison, WI: Soil Science Society of America, Inc.), 367-387.

Torrent, J., Barrón, V., and Liu, Q. S. (2006). Magnetic enhancement is linked to and precedes hematite formation in aerobic soil. Geophys. Res. Lett. 33, L02401. doi: $10.1029 / 2005 \mathrm{gl} 024818$

Torrent, J., and Cabedo, A. (1986). Sources of iron oxides in reddish brown soil profiles from calcarenites in southern Spain. Geoderma 37, 57-66.

Torrent, J., Liu, Q., and Barrón, V. (2010a). Magnetic minerals in Calcic Luvisols (Chromic) developed in a warm Mediterranean region of Spain: origin and paleoenvironemntal significance. Geoderma 154, 465-472. doi: 10.1016/j.geoderma.2008.06.020

Torrent, J., Liu, Q., and Barrón, V. (2010b). Magnetic susceptibility changes in relation to pedogenesis in a Xeralf chronosequence in northwestern Spain. Eur. J. Soil Sci. 61, 161-173. doi: 10.1111/j.1365-2389.2009.01216.x

Torrent, J., Liu, Q., Bloemendal, J., and Barrón, V. (2007). Magnetic enhancement and iron oxides in the Upper Luochuan loess-paleosol sequence, Chinese Loess Plateau. Soil Sci. Soc. Am. J. 71, 1570-1578. doi: 10.2136/sssaj2006.0328

Yaalon, D., and Dan, J. (1967). "Factors controlling soil formation and distribution in the Mediterranean coastal plain of Israel during the Quaternary," in Quaternary Soils, Proceedings of VII Congress of International Association of Quatarary Research, Vol. 9, 322-338.

Yaalon, D., and Ganor, E. (1973). The influence of dust on soils during the quaternary. Soil Sci. 116, 146-155.

Yaalon, D., and Ganor, E. (1979). "East Mediterranean trajectories of dust-carrying storms from the Sahara and Sinai," in Sharan Dust, ed C. Morales (Chichester: Wiley), 187-193.

Yaalon, D. H., Nathan, Y., Koyumdjisky, H., and Dan, J. (1966). "Weathering and catenary differentiation of clay minerals in soils on various parent materials in Israel," in Proceedings of the International Clay Conference, Vol. 1 (Jerusalem), $187-198$.

Yang, T., Hyodo, M., Zhang, S., Maeda, M., Yang, Z., Wu, H., et al. (2013). New insights into magnetic enhancement mechanism in Chinese paleosols. Palaeogeogr. Palaeoclimatol. Palaeoecol. 369, 493-500. doi: 10.1016/j.palaeo.2012.11.016

Zhang, C., and Guo, Z. (2014). Clay mineral changes across the EoceneOligocene transition in the sedimentary sequence at Xining occurred prior to global cooling. Palaeogeogr. Palaeoclimatol. Palaeoecol. 411, 18-29. doi: 10.1016/j.palaeo.2014.06.031

Zhang, C., and Pennington, J. (2004). African dry air outbreaks. J. Geophys. Res. 109, D20108 doi: 10.1029/2003jd003978

Conflict of Interest Statement: The authors declare that the research was conducted in the absence of any commercial or financial relationships that could be construed as a potential conflict of interest.

Copyright (C) 2016 Liu, Zhang, Torrent, Barrón, Hu, Jiang and Duan. This is an open-access article distributed under the terms of the Creative Commons Attribution License (CC BY). The use, distribution or reproduction in other forums is permitted, provided the original author(s) or licensor are credited and that the original publication in this journal is cited, in accordance with accepted academic practice. No use, distribution or reproduction is permitted which does not comply with these terms. 